Postgraduate Bosowa University Publishing (PBUP)
Indonesian Journal of Business and Management
e-ISSN: $2460-3767 \quad p$-ISSN: $2656-6885$

\title{
PENGARUH MOTIVASI DAN GAYA KEPEMIMPINAN TERHADAP KINERJA PEGAWAI PADA KANTOR RUMAH TAHANAN NEGARA KELAS IIB SELAYAR
}

\section{The Influence of Motivation and Leadership Style on The Performance of Employees in The Detention Center Class II B Selayar}

\author{
Hasnawati ${ }^{1}$, Muchtar Sapiri², Muhlis Ruslan ${ }^{3}$ \\ ${ }^{1}$ Magister Manajemen Universitas Universitas Bosowa \\ ${ }^{2}$ Program Studi Akuntansi Universitas Bosowa \\ ${ }^{3}$ Program Studi Manajemen Program Pascasarjana Universitas Bosowa \\ Email: nana6683.n6@gmail.com
}

Diterima: 16 Maret 2020 /Disetujui:05 Juni 2020

\begin{abstract}
ABSTRAK
Penelitian ini bertujuan buat mengetahui korelasi antara dampak motivasi serta gaya kepemimpinan terhadap kinerja pegawai pada rumah Tahanan Negara Kelas II B Selayar. Metode analisis yg dipergunakan merupakan analisis regresi linear berganda menggunakan contoh uji-t serta uji-f. Dari akibat pengujian regresi linear berganda diketahui bahwa motivasi serta gaya kepemimpinan secara Partial dan simultaneous berpengaruh positif serta significan terhadap hasil kerja pegawai. Hal ini sebagai bukti empiric bahwa indikator-indikator yg dipakai dalam kegiatan penelitian mengenai usaha kerja digunakan sebagai dasar buat peningkatan kinerja pegawai di pada tempat tinggal tahanan kelas II B Selayar. berasal yang akan terjadi uji regresi dapat dicermati bahwa variabel motivasi serta gaya kepemimpinan yang lebih bertenaga mempengaruhi peningkatan kinerja pegawai pada tempat tinggal tahanan kelas II B Selayar.
\end{abstract}

Kata Kunci: Motivasi, Gaya Kepemimpinan, Perbaikan Kinerja ${ }_{s}$ Rumah Tahanan, Selayar

\section{ABSTRACT}

This study aims to determine the correlation between the impact of motivation and leadership style on employees' performance in the Detention Center Class II B Selayar. The analytical method used is multiple linear regression analysis using the sample t-test and f-test. From the results of multiple linear regression testing, it is known that motivation and leadership style, partially and simultaneously, have positive and significant impacts on employees' work results. This is empirical evidence that the indicators used in this research activities regarding work effort are used as a basis for improving employees' performance in the Detention Center Class II B Selayar. From the regression test, it can be seen that motivation and leadership style variables significantly influence the improvement of employees' performance in the Detention Center Class II B Selayar.

Keywords: Motivation, Leadership Style, Performance Improvement, Detention Center, Selayar

\section{PENDAHULUAN}

Pemasyarakatan memberi arah, bahwa sistem pemasyarakatan diarahkan di pelatihan bimbingan serta perawatan terhadap masyarakat binaan pemasyarakatan. Upaya pencapaian tadi diharapkan langkah-langkah keamanan serta ketertiban sebagai akibatnya program dan sasaran bisa tercapai secara aporisma. Keamanan dan ketertiban lembaga pemasyarakatan artinya dasar dan sekaligus alat nilai buat keberhasaian dari yang melakukan tugas rumah tahanan. Cara ukur yg bisa menjadi alat mengetahui suatu kegiatan aman atau tertibnya suatu tempat tinggal tahanan mencakup taraf kenyamanan shingga tidak terjadi pelarian narapidana atau tahanan, perkelahian, pemberontakan, perjudian, perdagangan serta penyelundupan barang-barang terlarang (senjata, narkotika, serta obat terlarang lainnya). Oleh karena itu, tempat tinggal para tahanan berupaya secara porsinya buat dapat memantau, mencegah, dan menangkal gangguan keamanan serta 
ketertiban dari para tahanan. Kinerja dari pengertian prestasi, ada juga menyampaikan pengertian prestasi menjadi yang akan terjadi kerja atau prestasi kerja. tetapi sebenarnya kinerja memiliki makna yg lebih luas, bukan hanya akibat kerja, tetapi termasuk bagaimana proses pekerjaan berlangsung. Bangun (2012), menyebutkan bahwa meningkatnya prestasi adalah yg ingin dicapai yang bersumber daril pihak pemberi kerja juga para pekerja. Kata kinerja asal berasal kata job performance atau actual performance yaitu hasil kerja yang dicapai oleh pekerja dalam melaksanakan tugas dan tanggungjawab yang diberikan oleh pimpinan, hasil tersebut dapat dilihat dari segi jumlah maupun tangka kualitas. Kualitas dari produk kerja yang dihasilkan sangat ditentukan oleh kualitas sumber daya yang dimiliki yaitu tenaga kerja, dan untuk mendapatkannya banyak factor yang dapat mempengaruhinya baik secara internal maupun secara ekternal. Sperti halnya padaobyek penelitian yaitu pada Lembaga pemasyarakatan maka faktor yang terpenting adalah keterampilan dalam menjalankan tugasnya, karena tugas tugas tersebut banyak berhubungan dengan manusia sehingga sangatdiperlukan keterampilan yang tinggi dan pemahaman tehadap pribadi-peribadi yang ada dalam lingkungannya. Jadi menurut Mardiasmo pada Apriansyah dkk (2014), tentang hasil kerja suatu pegawai dapat dicapai melalui penentuan tujuan yang ingin dicapai, menghitung indicator masukan, mengetahui output yang dihasilkan, manfaat serta akibat yang dapat ditimbulkan. Sedagkan berdasarkan Cushway dalam Lina (2013) berkata bahwa kinerja diartikan menjadi suatu proses manajemen yg didesain buat dapat mengetaahui tujuan yang ingin dicapai dalam suatu organisasi dengan tujuan dari para pekerja yang ada dalam suatu organisasi.

Berdasarkan defenisi Gaya pemimpin di atas dapat dijelaskan bahwa gaya pemimpin merupakan suatu keahlian seorang dalam memberi arahan, mensugesti, memotivasi serta mengarahkan bawahan dan pegawai untuk dapat melakukan sesuatu tugasnya atas kesadarannya serta sukarela pada mencapai suatu tujuan eksklusif. Karena masih banyak dari pegawai yg belum disiplin serta tidak ada semangat pada bekerjanya, tidak waktu masuk kantor menggunakan alasan sedangang sakit, terlambat masuk kantor, tempat kerja ditinggalkan pada waktu kerja, kembali sebelum waktunya dan kurangnya ketepatan waktu yg digunakan dalam merampungkan tugas yang akan mensugesti kinerja yg didapatkan.

\section{METODE}

Jenis penelitian yang dipergunakan ialah penelitian kausalitas, penelitian kausal didukung meode penelitian secara kuantitatif. Metode penelitian kuantitatif, sebagaimana dikemukakan sang Sugiono (2012) yaitu metode penelitian yang berlandaskan di filsafat positivisme, dipergunakan buat meneliti di populasi atau sampel eksklusif, pengumpulan data menggunakan indtrumen penelitian, analisis data bersifat statistik menggunakan tujuan buat menguji hipotesis. Lokasi penelitian dilaksanakan pada tempat kerja tempat tinggal Tahanan Negara Kelas IIB Selayar, yg berlokasi di Jalan Emmy Syaelan No. 02 Kabupaten Kepulaun Selayar. Dilaksanakan di bulan Nopember 2019 hingga Januari 2020.

Populasi serta sampel pada penelitian ini memakai teknik sampling non probability (sampling jenuh), ialah semua anggota populasi dipergunakan menjadi sampel, (Sugiono 2012:85), dalam hal ini seluruh pegawai di kantor tempat tinggal Tahanan Negara Kelas IIB Selayar yg berjumlah 51 orang yang terdiri asal golongan II berjumlah 27 orang serta golongan III berjumlah 24 orang. Variabel Penelitian yg dipergunakan ialah variabel Bebas (Independen Variabel), Variabel independen ialah variabel yg mempengaruhi serta yang sebagai penyebab timbulnya variabel dependen (Sugiono, 2011). dalam penelitian ini yg menjadi variabel independen yang terdiri berasal; motivasi dan gaya kepemimpinan serta variabel terikat (Dependen Variabel), artinya variabel yang dipengaruhi atau menjadi dampak, karena adanya variabel bebas (Sugiono, 2011). dalam penelitian ini yang menjadi variabel terikat (dependen variabel) merupakan Kinerja Pegawai.

Instrumen Penelitian yang digunakan buat mengumpulkan data utama berupa daftar pertanyaan (berita umum) yg disusun dalam bentuk angket terstruktur menggunakan memakai skala likert yang diberi nilai tertinggi lima (lima) dan nilai terendah 1 (satu). Pengumpulan data menggunakan memakai berita umum dilakukan menggunakan tekhnik interview atau wawancara terpimpin yg berpedoman di berita umum yang terdapat. Ghozali (2005), skala linkert merupakan skala yg berisi lima tingkat preferensi jawaban menggunakan pilihan menjadi berikut; 1 (sangat tidak sepakat), 2 (tidak setuju, tiga (kurang putusan bulat), 4 (putusan bulat), serta lima (sangat setuju). Teknik Analisa Data pada penelitian ini menggunakan empat metode, yaitu uji kualitas data, uji perkiraan klasik, analisis regresi linear berganda serta uji hipotesis. Dikatakan valid Bila pertanyaan atau pernyataan pada informasi lapangan bisa berkata sesuatu yang akan diukur sang kuesioner tersebut. dari Ghozali (2016) mengukur validitas bisa dilakukan dengan cara melakukan hubungan abtar skor buah pertanyaan dengan total skor konstruk atau variabel. Pengujian reliabilitas bertujuan buat mengukur survey yang merupakan indikator dari variabel atau konstruk. Ghozali (2016) menyatakan bahwa suatu survey dikatakan reliabel atau handal Jika jawaban asal responden terhadap pertanyaan artinya konsisten atau stabil asal ketika ke waktu. menurut Nunnally (1969) pada Ghozali (2016) Mensyaratkan suatu instrumen yang reliabel Jika memiliki koefisien Cronbach Alpha > 0,07 . Uji reabilitas dipergunakan untuk mengetahui 
konsistensi indera ukur, apakah indera ukur yang digunakan dapat dipercaya serta tetap konsisten Jika pengukuran tersebut diulang. Uji asumsi Klasik memakai empat uji, yaitu uji normalitas, uji multikolineraritas, uji heteroskedastisitas serta uji autokorelasi. Uji Normalitas bertujuan buat mngetahui apakah variabel dependen, independen atau keduanya berdistribusi normal, mendekati normal atau tidak. model regresi yang baik adalah mempunyai distribusi normal atau mendekati normal (Umar, 2010).

$$
y=\beta_{o}+\beta_{1} X_{1}+\beta_{2} X_{2}
$$

dimana:

$$
\begin{aligned}
& \mathrm{y}=\text { kinerja pegawai Lembaga } \\
& \mathrm{Bo}=\text { konstanta } \\
& \beta 1 \mathrm{X} 1=\text { nilai koefisien } \\
& \mathrm{X} 1=\text { motivasi } \\
& \mathrm{X} 2=\text { gaya pemimpin } \\
& e=\text { tingkat error }
\end{aligned}
$$

\section{HASIL DAN PEMBAHASAN}

Prestasi pegawai memberikan kontribusi besar didalam usaha buat tercapainya tujuan suatu organisasi tanpa terkecuali pada tempat tinggal Tahanan Negara Kelas IIB Selayar. Kinerja pada prinsipnya diartikan menjadi akibat kegiatan yang dilakukan dengan melihat kuantitas dan secara kualitas sehingga dicapai sinkron dengan pemberian tanggung jawab kepadanya (Mangkunegara, 2009). Menjadi tempat tinggal Tahanan seharusnya hanya menerima tahanan saja, namun sebab pada Selayar belum terdapat lembaga Pemasyarakatan maka Rutan Kelas IIB Selayar juga mendapatkan tahanan serta narapidana. Beban tugas yg besar itulah penerapan motivasi kinerja yang tinggi pada bekerja sangat dibutuhkan buat memperoleh akibat kerja yg maksimal. Faktor-faktor yg bisa dipergunakan buat menaikkan kinerja pegawai merupakan motivasi serta gaya kepemimpinan. Morgan et al. (dalam Marwansyah serta Mukaram, 2002) menjelaskan bahwa motivasi adalah kekuatan yg mengendalikan serta menggerakkan seseorang buat melakukan tindakan atau perilaku yang diarahkan di tujuan tertentu. Robbin (2002) mengemukakan bahwa motivasi adalah impian buat melakukan sesuatu sebagai kesediaan buat mengeluarkan tingkat upaya yang tinggi demi tujuantujuan organisasi, yg dikondisikan sang kemampuan upaya itu buat memenuhi suatu kebutuhan individual.

Keberhasilan suatu organisasi atau instansi baik yang bergerak pada sektor sosial atau sektor publik maupun sektor maupun pada sector dengan orientasi profit sangat diperlukan suatu motivasi, dengan motivasi dapat meningkatkan prestasi kerja dan menghasilkan manfaat bagi semua pihak, dengan motivasi yang tinggi pada oranisasi seperti pelaksanaan rumah tahanan sangat dibutuhkan, sehingga yang ada dalam tahanan tersebut melasa tidak dalam keadaan dihukum karena adanya motivasi dari semua pihak yaitu dari pegawai dan juga pemberian motivasi kepada manusia yang sedang mengalami tahanan, motivasi yang diberikan adalah bagaimana menumbuhkan kepercayaan diri dengan berbagai pekerjaan yang dapat dilaksanakan yang dapat memberi pengetahuan kepada tahanan tersebut, sehingga pada saatnya nanti setelah terjun ketengahtengah masyarakat tidak melakukan yang sifatnya negative dan dapat meningkatkan produktivitasnya dalam memenuhi kebutuhan hidupnya.

Anugerah terbesar dengan adanya motivasi memberikan imbas positif pada aplikasi dalam melakukan pekerjaan bagi aparat pegawai sehingga pencapaian dari target kerja organisasi, tetapi fenomena pada kenyataannya membagikan tanda masing kurang dari motivasi yang dipunya dari pegawai didalam melaksanakan kewajibannya. Motivasi yg rendah dapat menghasilkan seorang yang punya kualitas kinerja yg rendah dan kebalikannya (Rivai, 2005). Setiap organisasi tentunya memiliki sebuah tujuan. pada pencapaian tujuan tadi diperlukan sumber daya manusia yang mempunyai motivasi tinggi. Pengertian motivasi berdasarkan Bangun (2012), berkata bahwa motivasi artinya suatu syarat yg memotivasi orang lain buat bisa menjalankan tugas sinkron menggunakan manfaatnya dalam suatu institusi. Selain itu dari Barelson dan steiner pada sunyonto danang (2013), motivasi ialah suatu perjuangan sadar buat menghipnotis sikap seseorang supaya menunjuk tercapainya tujuan organisasi. Selanjutnya dari Jerald Greenberg serta Robert pada Wibowo (2012), menyatakan bahwa motivasi artinya suatu rangkaian proses yang membangkitkan, mengarahkan serta menjaga perilaku manusia menuju di pencapaian tujuan. sesuai pengertian tentang motivasi di atas maka sebagai simpulan bahwa dengan motivasi yang tinggi dapat menjadi pendoroong dan penyemangan bagi seseorang dalam menjalan tugasnya sehingga hasil yang didapat menjadi ukuran kinerja dalam menjalankan tugas yang diberikan, dengan motivasi dapat menjadi pemberi arah pada tingkah lakunya, keliru satunya dorongan seseorang buat belajar.

Selah satu elemen krusial yang dapat menghipnotis kinerja pegawai ialah gaya kepemimpinan. Koesmono (2007) mengatakan eksistensi seorang pimpinan pada suatu Lembaga diperlukan buat membawa lembaga kepada tujuan yang sudah ditentukan. Menurut Robert House, bila pemimpin memberi motivasi yang lebih besar terhadap pemenuhan harapan tadi, maka semakin besar pula prestasi yg akan diperoleh para pegawainya. sang karena itu, kepemimpinan akan mempengaruhi kinerja pegawai. Gaya kepemimpinan yg baik merupakan gaya kepemimpinan yg dapat menyampaikan motivasi kerja di bawahannya. Ivancevich (2001), Ahmad et al., (2020) dan Widyatmini dan Hakim (2008) mengatakan, seseorang pemimpin wajib menyatukan aneka macam keahlian, pengalaman, kepribadian dan motivasi. Kinerja karyawan akan baik bila pimpinan dapat memberi motivasi yg sempurna dan pimpinan mempunyai gaya kepemimpinan yg bisa diterima oleh seluruh karyawan 
serta mendukung terciptanya suasana kerja yang baik. Pamudji (1993), menyatakan bahwa kepemimpinan tadi artinya suatu "seni" buat menyamakan mindset atau persepsi berasal setiap anggota Organisasi dalam penmencapai tujuan organisasi. Hal yg sarna dikemukakan sang Daft (2010) pada Yusuf (2013) "However, transformational leaders capable to implement the changes in vision, mission, and organization culture Alaihi Salam a whole by influencing his subordinates to make changes to increase productivity or performance of organization." bahwa pemimpin transformasional yg mampu menerapkan perubahan pada visi, misi, serta budaya organisasi secara keseluruhan menggunakan mensugesti bawahannya membuat perubahan buat menaikkan produktivitas atau kinerja organisasi. Setiap pemimpin intinya memiliki sikap yg berbeda pada dalam mengarahkan para pengikutnya, perilaku para ini diklain sebagai suatu model dalam mengarahkan bahawannya. Model pemimpin artinya bagaimana usaha yang dilakukan dalam menrahkan bahannya sehingga dalam melaksanakan tugas yang diberikan dan berdasarkan program dilaksanakan dengan baik. Cara-cara menrahkan bawahan berbeda-beda dari berbagai Lembaga tergantung tujuan yang ingin dicapai. Lembaga pemasarakan seorang pimpinan berusaha memberi pengarahan kepada bawahannya dalam melaksanakan tugas betul-betul mengayomi ini dapat memberi motvasi kepada pegawai, sehingga semua komponen memberi hasil yang sesuai dengan harapan pimpinan. Berdasarkan Thoha (2010) mengemukakan bahwa: model kepemimpinan adalah suatu cara berprilaku yang digunakan oleh seseorang di ketika orang tersebut mencoba menghipnotis prilaku orang lain atau bawahan. menurut Hasibuan (2013), gaya kepemimpinan artinya cara seseorang pemimpin mempengaruhi sikap bawahan, supaya mau bekerja sama dan bekerja secara produktif untuk mencapai tujuan organisasi.

\section{Karakteristik Responden}

Ciri responden yg diukur menggunakan skala nominal yg menunjukkan besarnya frekwensi pasti serta presentase jenis kelamin, umur responden, pendidikan terakhir responden dan lama jabatan responden. Responden yang digunakan pada penelitian ini adalah pegawai kantor rumah Tahanan Negara Kelas IIB Selayar. berita umum disebar menggunakan asa bisa diisi berdasarkan pegawai, sehingga akan membuat suatu penelitian yang balance. pada ciri responden, diambil 51 sebagai sumber informan yang terdiri dari para pegawai rumah Tahanan Negara Kelas IIB Selayar. Data tentang karakteristik responden ditampilkan di Tabel 1.
Tabel 1 Responden Berdasarkan Karakteristik Jenis Kelamin

\begin{tabular}{lcc}
\hline \multicolumn{1}{c}{ Uraian } & jumlah & presentase $(\%)$ \\
\hline Laki-laki & 41 & 80 \\
Perempuan & 10 & 10 \\
\hline Total & 51 & 100 \\
\hline
\end{tabular}

Sumber: data diolah kembali, 2019

Sesuai jenis kelamin memberi gambaran dari responden mengenai jenis kelamin yang mendominasi adalah laki-laki, dengan jumlah sebesar 41 dari responden atau $80 \%$ serta 10 respondent atau 20\% artinya wanita. Laki-laki yang banyak pegawainya hal ini menunjukkan bahwa tenaga dalam pekerjaan ini membutuhkan tenaga yang kuat dan keras karena menjaga Lembaga pemasyarakatan, pekerjaan pada Lembaga membutuhkan waktu 24 jam dalam menjalan tugasnya, walaupun tenaga kerja yang bertugas saling bergantian dalam menjalnkan tugasnya, beda dengan tenaga perempuan banyak melakuka kerja administrasif sehingg tidak telalu membutuhakan waktu dan tenaga yang berat. Untuk data tingkat jarak umur;

Tabel 2 Responden dengan Karakteristik Tingkat Umur

\begin{tabular}{ccc}
\hline Umur & Jumlah & Presentase $(\%)$ \\
\hline $21-30$ tahun & 25 & 49 \\
$31-40$ tahun & 7 & 14 \\
$>40$ tahun & 19 & 37 \\
\hline Total & 51 & 100 \\
\hline
\end{tabular}

Sumber: data diolah kembali, 2019

Berdasarkan Tabel 2 diatas sesuai tingkat umur dari responden diperlihatkan antara sebagai informan berumur 21 - 30 tahun dengan jumlah 25 sebagai informan atau sebanyak $49 \%$, umur dari informan antara 31 - 40 tahun sebanyak 7 orang dengan sebesar $14 \%$, umur diatas 40 tahun berjumlah 19 orang sebanyak $37 \%$.

Tabel 3 Responden dengan Karakteristik Pendidikan Terakhir

\begin{tabular}{ccc}
\hline Deskripsi & Jumlah & Presentase $(\%)$ \\
\hline SMK/Sekolah & 33 & 65 \\
Menengah & 1 & 2 \\
DIII & 16 & 31 \\
S-1 & 15 & 2 \\
S-2 & & 100
\end{tabular}

Sumber: data diolah kembali, 2019

Berdasarkan olah data menujukkan gambaran besarnya Pendidikan terakhir dari informan dimiliki dalam hal ini para responden memperlihatkan responden mempunyai berpendidikan SMK/Sekolah Menengan Atas berjumlah 33 responden atau sebesar 65\%, sedangkan dengan pendidikan D-III hanya sebanyak 1 orang atau sebesar $2 \%$, untuk yang berpendidikan S-1 menjadi responden dalam penelitian ini sebanyak 16 orang secara prosentase $31 \%$, sedangkan yang mempunyai Pendidikan tingat Pendidikan yang lebih tinggi sampai tingkat S-2 hanya berjumlah 1 orang atau sebanyak 2\%.Dari jenjang Pendidikan yang diikuti oleh para petugas Lembaga pembaga pemasarakat Selayar 
masih sangat kurang artinya diperlukan tingkat Pendidikan yang banyak mengerjakan sifatnya teknis dan pemberi pencerahan kepada masyarakat menghubi rumah tahanan, seperti jurusan psikologi sangat diperlukan sehingga dapat memberi konstribusi yang besar terhadap perubahan pola piker dari penghuni rumah tahan, begitu juga jurusan dengan tingkat D-III seharusnya lebih banyak sehingga dapat lebih banyak memberi bantuan dalam meningkatkan pegetahuan yang sifatnya dapat meningkatkan usaha ekonomi kedepannya.

Tabel 4 Responden dengan Karakteristik Berdasarkan Lama Jabatan

\begin{tabular}{ccc}
\hline Umur & Jumlah & Presentase $(\%)$ \\
\hline $1-5$ & 21 & 41 \\
$6-10$ & 6 & 12 \\
$11-15$ & 3 & 6 \\
$16-20$ & 1 & 2 \\
$>20$ & 20 & 39 \\
\hline Total & 51 & 100 \\
\hline
\end{tabular}

Sumber: data diolah kembali, 2019

Dari data memberikan informasi yaitu antara 1-5 sebagai informan mencapai 21 orang, untuk umur dari 6-10 berjumlah 6 orang informan atau $12 \%$, untuk umur antara 11-15 berjumlah 3 orang informan atau $6 \%$, untuk umur antara 16-20 orang informan berjumlah 1 orang atau hanya $2 \%$ informan, sedangkan umur diatas 20 tahun sebnyak 20 orang informan atau 39\%. Dari data tersebut menujukkan bahwa lama menjabatan sebagai sumber informan rata-rata hanya lima tahun, diharapkan walaupun masih minim pengamalam namun telah memahami dari Lembaga pemasarakan sehingga dapat memberi penjelasan yang dapat mengarbarkan kondisi sebenarnya.

1. Deskripti Variabel

Intinya dari kegiatan ini bertujuan buat menganalisa impak motivasi, gaya kepemimpinan terhadap kinerja pegawai di tempat kerja rumah Tahanan Negara Kelas IIB Selayar yg beralamat pada Jl. Emmy Syaelan No. 2 Kec. Benteng Kabupaten Kepualauan Selayar. Penelitian ini ada 2 variabels independen terdiri motivasi dan gaya kepemimpinan dan variabel dependen yaitu kinerja pegawai. Penelitian ini dilakukan dengan memakai data utama, yaitu data yg diperoleh pribadi asal kantor pemerintahan lingkup Kecamatan Pangkajene dan data sekunder yang diperoleh asal akibat hitungan acara SPSS Versi 21 For Windows melalui akibat jawaban karyawan yang diberikan memalui koesioner.

\section{Deskripsi Variabel Motivasi}

Motivasi merupakan adanya tuntutan atau dorongan terhadap pemenuhan kebutuhan individu serta tuntutan atau dorongan yg asal berasal lingkungan, kemudian diimplementasikan dalam bentuk sikap.
Tabel 5 Deskripsi Variabel Motivasi

\begin{tabular}{|c|c|c|c|c|c|c|c|c|c|c|c|c|c|}
\hline \multirow{3}{*}{ Item } & \multicolumn{10}{|c|}{ Skor } & \multirow{2}{*}{\multicolumn{2}{|c|}{ Total }} & \multirow{3}{*}{$\begin{array}{l}\text { Rata } \\
\text { skor }\end{array}$} \\
\hline & \multicolumn{2}{|c|}{ Ss (5) } & \multicolumn{2}{|c|}{ s (4) } & \multicolumn{2}{|c|}{$\mathrm{n}(3)$} & \multicolumn{2}{|c|}{ Ts (2) } & \multicolumn{2}{|c|}{ STS (1) } & & & \\
\hline & $\mathrm{f}$ & $(\%)$ & $\mathrm{f}$ & $(\%)$ & $\mathrm{f}$ & $(\%)$ & $\mathrm{f}$ & $(\%$ & $\mathrm{f}$ & $\%$ & $\sum \mathrm{F}$ & $\sum \%$ & \\
\hline PM1 & 25 & 49,1 & 19 & 37,2 & 5 & 9,8 & - & - & 3,9 & - & 51 & 100 & 12,75 \\
\hline PM2 & 43 & 84,3 & 8 & 15,6 & - & - & - & - & - & - & 51 & 100 & 25,5 \\
\hline PM3 & 35 & 68,6 & 16 & 31,3 & - & - & - & - & - & - & 51 & 100 & 25,5 \\
\hline PM4 & 29 & 56,8 & 20 & 39,2 & 2 & 3,9 & - & - & - & - & 51 & 100 & 4,39 \\
\hline PM5 & 31 & 60,7 & 19 & 37,2 & 1 & 1,9 & - & - & - & - & 51 & 100 & 8,65 \\
\hline PM6 & 31 & 60,7 & 20 & 39,2 & - & - & - & - & - & - & 51 & 100 & 8,22 \\
\hline PM7 & 34 & 66,6 & 15 & 29,4 & 1 & 1,9 & 1 & 1,9 & - & - & 51 & 100 & 12,5 \\
\hline PM8 & 35 & 68,6 & 14 & 27,4 & 2 & 3,9 & - & - & - & - & 51 & 100 & 5,20 \\
\hline PM9 & 39 & 76,4 & 12 & 23,5 & - & - & - & - & - & - & 15 & 100 & 10,8 \\
\hline $\begin{array}{c}\text { PM1 } \\
0\end{array}$ & 34 & 66,6 & 17 & 33,3 & & & - & - & - & - & 51 & 100 & 8,82 \\
\hline
\end{tabular}

Sumber: data diolah kembali, 2019

Dari informan menyampaikan tanggapan Sangat putusan bulat serta setuju terhadap pengukuran motivasi. Pertanyaan pertama jawaban sangat sepakat menerima $49,1 \%$, putusan bulat $37,2 \%$, normal $9,8 \%$, sangat tak setuju 3,9\%. Pertanyaan kedua jawaban sangat setuju $84,3 \%$, sepakat $15,6 \%$. Pertanyaan ketiga sangat sepakat $68,6 \%$ setuju $31,1 \%$. Pertanyaan keempat jawaban sangat setuju 56,8\%, sepakat $39,2 \%$, netral $3,9 \%$. Pertanyaan kelima jawaban sangat sepakat $60,7 \%$, putusan bulat $37,2 \%$, netral $1,9 \%$. Pertanyaan keenam jawaban sangat putusan bulat $60,7 \%$, putusan bulat 39 ,dua\%. Pertanyaan ke 7 jawaban sangat setuju 66,6\%, sepakat $29,4 \%$, netral $1,9 \%$, tidak sepakat $1,9 \%$. Pertanyaan kedelapan jawaban sangat setuju $68,6 \%$, sepakat $27,4 \%$, netral $3,9 \%$. Pertanyaan kesembilan jawaban sangat setuju $76,4 \%$, sepakat $23,5 \%$. Pertanyaan kesepuluh jawaban sangat setuju $66,6 \%$, setuju $33,3 \%$.

3. Deskripsi Variabel Gaya Kepemimpinan

Gaya ialah cara memberi pengaruh buat memahami dan sepakat wacana apa yang akan dikerjakan serta bagaimana tugas itu bisa dilakukan secara efektif, serta proses memfasilitasi usaha individu serta kelompok buat mencapai tujuan organisasi.

Tabel 6 Deskripsi Variabel Gaya Kepemimpinan

\begin{tabular}{|c|c|c|c|c|c|c|c|c|c|c|c|c|c|}
\hline \multirow{3}{*}{ Item } & \multicolumn{10}{|c|}{ Skor } & \multirow{2}{*}{\multicolumn{2}{|c|}{ Total }} & \multirow{3}{*}{$\begin{array}{l}\text { Rata } \\
\text { skor }\end{array}$} \\
\hline & \multicolumn{2}{|c|}{ Ss (5) } & \multicolumn{2}{|c|}{ s (4) } & \multicolumn{2}{|c|}{ n (3) } & \multicolumn{2}{|c|}{ Ts (2) } & \multicolumn{2}{|c|}{ STS (1) } & & & \\
\hline & f & $(\%)$ & f & $(\%)$ & f & $(\%)$ & f & $(\%$ & f & $\%$ & $\sum F$ & $\sum_{\%}$ & \\
\hline GK1 & 32 & 62,7 & 19 & 37,2 & - & - & - & - & - & - & 51 & 100 & 8,38 \\
\hline GK2 & 27 & 52,9 & 23 & 45,1 & 1 & 1,9 & - & - & - & - & 51 & 100 & 8,21 \\
\hline GK3 & 32 & 62,7 & 19 & 37,2 & - & - & - & - & - & - & 51 & 100 & 8,38 \\
\hline GK4 & 30 & 58,8 & 20 & 39,2 & 1 & 1,9 & - & - & - & - & 51 & 100 & 8,5 \\
\hline GK5 & 30 & 58,8 & 20 & 39,2 & 1 & 1,9 & - & - & - & - & 51 & 100 & 8,5 \\
\hline GK6 & 35 & 68,6 & 16 & 6,25 & - & - & - & - & - & - & 51 & 100 & 9,10 \\
\hline GK7 & 35 & 68,6 & 15 & 29,4 & 1 & 1,9 & - & - & - & - & 51 & 100 & 9,71 \\
\hline GK8 & 30 & 58,8 & 20 & 39,2 & - & - & - & - & 1 & 1,9 & 51 & 100 & 8,5 \\
\hline GK9 & 30 & 58,8 & 21 & 41,7 & - & - & - & - & - & - & 15 & 100 & 9,0 \\
\hline GK10 & 36 & 70,5 & 13 & 25,4 & - & - & - & - & - & - & 51 & 100 & 10,8 \\
\hline
\end{tabular}

Sumber: data diolah kembali, 2020

Berasal Tabel 6 pada atas menunjukkan bahwa sebagian akbar responden memberikan tanggapan Sangat putusan bulat dan putusan bulat terhadap item-item pengukuran gaya kepemimpinan. Pertanyaan pertama jawaban sangat setuju menerima $62,7 \%$, sepakat $37,2 \%$. Pertanyaan kedua jawaban sangat setuju 52,9\%, putusan bulat $45,1 \%$, netral $1,9 \%$. Pertanyaan ketiga sangat setuju $62,7 \%$ setuju 37,dua\%. Pertanyaan keempat jawaban sangat sepakat $58,8 \%$, setuju $39,2 \%$, netral $1,9 \%$. 
Pertanyaan kelima jawaban sangat setuju 58,8\%, setuju 39 ,dua $\%$, netral $1,9 \%$. Pertanyaan keenam jawaban sangat sepakat $68,6 \%$, setuju 6,25\%. Pertanyaan ke 7 jawaban sangat setuju $68,6 \%$, sepakat $29,4 \%$, netral $1,9 \%$. Pertanyaan kedelapan jawaban sangat putusan bulat $58,8 \%$, setuju $39,2 \%$, sangat tidak putusan bulat $1,9 \%$. Pertanyaan kesembilan jawaban sangat sepakat $58,8 \%$, sepakat $41,7 \%$. Pertanyaan kesepuluh jawaban sangat sepakat $70,5 \%$, setuju $25,4 \%$.

4. Deskripsi Variabel Kinerja Pegawai

Kinerja ialah suatu fungsi dari motivasi dan kemampuan buat menuntaskan tugas atau pekerjaan seorang harus memiliki derajat kesediaan serta tingkat kesediaan eksklusif, kesediaan serta keterampilan seseorang tidaklah relatif efektif untuk mengerjakan sesuatu tanpa pemahaman dan pengertian yg jelas perihal apa yang akan dikerjakan dan bagaimana cara mengerjakannya.

Tabel 7 Deskripsi Variabel Kinerja

\begin{tabular}{|c|c|c|c|c|c|c|c|c|c|c|c|c|c|}
\hline \multirow{3}{*}{ Item } & \multicolumn{10}{|c|}{ Skor } & \multirow{2}{*}{\multicolumn{2}{|c|}{ Total }} & \multirow{3}{*}{$\begin{array}{l}\text { Rata } \\
\text { skor }\end{array}$} \\
\hline & \multicolumn{2}{|c|}{ Ss (5) } & \multicolumn{2}{|c|}{ s (4) } & \multicolumn{2}{|c|}{$\mathrm{n}(3)$} & \multicolumn{2}{|c|}{ Ts (2) } & \multicolumn{2}{|c|}{ STS (1) } & & & \\
\hline & f & $(\%)$ & f & $(\%)$ & f & $(\%)$ & f & (\% & f & $\%$ & $\sum F$ & $\sum_{\%}$ & \\
\hline KP1 & 30 & 58,8 & 21 & 41,7 & - & - & - & - & - & - & 51 & 100 & 9,0 \\
\hline KP2 & 35 & 68,6 & 16 & 6,25 & - & - & - & - & - & - & 51 & 100 & 9,10 \\
\hline KP3 & 36 & 70,5 & 15 & 29,4 & - & - & - & - & - & - & 51 & 100 & 9,44 \\
\hline KP4 & 32 & 62,7 & 17 & 33,3 & 1 & 1,9 & - & - & - & - & 51 & 100 & 9,37 \\
\hline KP5 & 35 & 68,6 & 16 & 6,25 & - & - & - & - & - & - & 51 & 100 & 9,10 \\
\hline KP6 & 36 & 70,5 & 15 & 29,4 & - & - & - & - & - & - & 51 & 100 & 9,44 \\
\hline KP7 & 37 & 72,5 & 14 & 27,4 & - & - & - & - & - & - & 51 & 100 & 9,84 \\
\hline KP8 & 32 & 62,7 & 19 & 37,2 & - & - & - & - & - & - & 51 & 100 & 8,38 \\
\hline KP9 & 34 & 66,6 & 17 & 33,3 & - & - & - & - & - & - & 15 & 100 & 8,82 \\
\hline KP10 & 38 & 74,5 & 13 & 25,4 & - & - & - & - & - & - & 51 & 100 & 10,32 \\
\hline
\end{tabular}

Tabel 7 pada atas memberikan bahwa sebagian besar responden menyampaikan tanggapan Sangat setuju dan setuju terhadap item-item pengukuran kinerja. Pertanyaan pertama jawaban sangat setuju menerima $58,8 \%$, putusan bulat $41,7 \%$. Pertanyaan ke 2 jawaban sangat sepakat $68,6 \%$, setuju $6,25 \%$. Pertanyaan ketiga sangat setuju 70,5\% sepakat 29,4\%. Pertanyaan keempat jawaban sangat sepakat $62,7 \%$, setuju 33,3 , netral $1,9 \%$. Pertanyaan kelima jawaban sangat setuju $68,6 \%$, sepakat $6,25 \%$. Pertanyaan keenam jawaban sangat sepakat $70,5 \%$, setuju $29,4 \%$. Pertanyaan ketujuh jawaban sangat putusan bulat $72,5 \%$, setuju $27,4 \%$. Pertanyaan kedelapan jawaban sangat sepakat 62,7\%, setuju 37,dua\%. Pertanyaan kesembilan jawaban sangat putusan bulat $66,6 \%$, sepakat $33,3 \%$. Pertanyaan kesepuluh jawaban sangat setuju $74,5 \%$, sepakat $25,4 \%$.

Imbas motivasi serta gaya kepemimpinan tehadap peningkatan kinerja pegawai rumah Tahanan Negara Kelas IIB Selayar. dapat dijelaskan uji hipotesis yang dilakukan secara parsial bahwa Motivasi (H1) yg mengungkapkan bahwa motivasi berpengaruh positif terhadap kinerja manajerial. Hal ini ditunjukkan bahwa nilai koefisien regresi variable motivasi (X1) artinya 0,512 , nilai thitung 3.057 ttabel 1,64 . $p$ value sebanyak 004. yang akan terjadi ini menyebutkan bahwa nilai koefisien regresi variabel motivasi (X1) berpengaruh positif terhadap kinerja pegawai. Gaya kepemimpinan
(H2) yg menyebutkan bahwa gaya kepemimpinan berpengaruh positif terhadap kinerja manajerial. Hal ini ditunjukkan bahwa nilai koefisien regresi variable motivasi (X2) ialah 0,252 , nilai t hitung 1.602 , berasal akibat penelitian hubungan antara motivasi dengan kinerja, diperoleh hubungan ke 2 variabel berubungan positif dan berpengeruh secara signifikan dimana nilai signifikasinya lebih mungil berasal tingkat signifikan yaitu 0,04 dan 0,05 . Hal ini berarti bahwa semakin tinggi motivasi pegawai di tempat tinggal Tahanan Negara kelas IIB Selayar, maka akan menaikkan kinerja pegawai. berasal yang akan terjadi penelitian korelasi antara gaya kepemimpinan dan kinerja diperoleh korelasi kedua variabel berafiliasi positif dan berpengaruh tetapi tidak signifikan, dimana nilai signifikan Sig nya lebih besar dari tingkat signifikasi yaitu 1,6 serta 0,05 . Hal ini berarti bahwa semua kewenangan dan tanggungjawab pimpinan dilaksanakan sang bawahannya.

\section{SIMPULAN}

Hasil penelitian menyimpulkan bahwa gaya kepemimpinan tidak memberikan dampak terhadap kinerja pegawai di di kantor tempat tinggal Tahanan Negara Kelas IIB Selayar.

\section{DAFTAR PUSTAKA}

Ahmad, N. A. R., Muhtar, M., \& Abubakar, H. (2020). Pengaruh Lingkungan Kerja, Kepemimpinan Dan Pengendalian Diri (Locus Of Control) Terhadap Kinerja Pegawai Melalui Kepuasan Kerja Di Dinas Kominfo Kabupaten Pangkep. Indonesian Journal of Business and Management, 2(1), 28-34.

Apriansyah, Ginanjar, dkk. (2014). "Pengaruh Partisipasi Anggaran, Komitmen Organisasi, Kepuasan Kerja, JOB-Relevant information dan Budaya Organisasi Terhadap Kinerja Manajerial pada Perhotelan di provinsi Riau" Jurnal Akuntansi.2014. efektif (Study pada Bank BRI Cabang Wates). Universitas Diponegoro.

Ghozali, Imam (2006). Aplikasi analisis multivariate dengan program SPSS Cetakan Keempat. Semarang: Badan Penerbit Universitas Diponegoro . (2013). "Aplikasi Analisis Multivariate Dengan Progran IBM SPSS 21”. Semarang: Badan Penerbit Universitas Diponegoro.

2005. "Analisis Dengan Program SPSS.” Semarang: Badan Penerbit-Undip

. (2016). "Aplikasi Analisis Multivariete Dengan Program IBM SPSS”. Semarang: Badan Penerbit Universitas Diponegoro

Hasibuan, Malayu 2013. "Manajemen Sumber Daya Manusia." Cetakan Ketujuh Belas. PT Bumi Aksara, Jakarta.

Koesmono, H. Teman, 2007. Pengaruh Kepemimpinan Dan Tuntutan Tugas Terhadap Komitmen Organisasi Dengan Variabel Moderasi Motivasi 
Perawat Rumah Sakit Swasta Surabaya. Jurnal Manajemen Dan Kewirausahaan, Vol. 9, No. 1, Maret 2007: 30-40.

Lina dan Stella.2013. "Pengaruh Partisipasi penyusunan Anggaran terhadap Kinerja Manajerial: Kepuasan Kerja dan Job Relevant Information sebagai Variabel Intervening. Jurnal Bisnis dan Akuntansi”, Vol. 15. No. 1:37-56.

Mangkunegara, A.A Anwar Prabu. 2009. "Manajemen Sumber Daya Manusia". Bandung: PT. Remaja Rosdakarya.

Marwansyah dan MMangkunegara, Anwar Prabu, 2005. Perilaku dan Budaya Organisasi, Cetakan Pertama, PT. Refika Aditama, Bandung

Pamudji, S. 1993. "Ekologi Administrasi Negara". Jakarta: Bumi Aksara.

Rivai dan Basri (2005). Performance Appraisal. Jakarta: PT Raja, Grafindo Persada

Robbin, S 2008. Perilaku Organisasi, Jilid I dan II, Alih Bahasa : Hadyana Pujaatmaja. Jakarta : Prenhallindo

Sugiono, 2010. Metode Penelitian Kuantitatif, Kualitatif dan R\&D. Bandung : Alfabeta.

2011. "Metode Penelitian Pendidikan (Pendekatan Kuantitatif, Kualitatif, dan R\&D)"; Alfabeta. Bandung.

Thoha Miftah., (2010), "Pembinaan Organisasi, proses diagnosa dan intervensi, Manajemen pengaruh budaya dan komitmen organisasi serta hubungannya antara partisipasi penganggaran dan kinerja manajerial perusahaan amdk di pasuruan. universitas muhammadiyah malang Kepemimpinan". Yogyakarta, Gava Media.

Umar, Husein. 2008. Metode Penelitian untuk Skripsi dan Tesis Bisnis. Jakarta: PT Raja Grafindo Persada.

Wibowo. 2012. "Manajemen Kinerja” Jakarta. PT Raja Grafindo Persada.

Widyatmini dan Hakim, lukman.2008. "Hubungan Kepemimpinan, Kompensasi dan Kompetensi Terhadap Kinerja Pegawai Dinas Kesehatan Kota Depok"

Wilson, Bangun. 2012. "Manajemen Sumber Daya Manusia", Jakarta, Erlangga.

Yusuf. 2013. Pengaruh Pengalaman, Independensi, dan Skeptisme Profesional Auitor terhadap pendeteksian kecurangan. Fakultas Ekonomi dan Ilmu Sosial UIN Syarif Hidayatullah Jakarta 